\title{
Management of foreign body ingestion and food impaction in adults: A cross-sectional study
}

\author{
İsmail Okan, M.D., ${ }^{1} \oplus$ Ahmet Akbaş, M.D., ${ }^{1} \odot$ Mustafa Küpeli, M.D., ${ }^{2} \odot$ Abdullah Özgür Yeniova, M.D., ${ }^{3}$

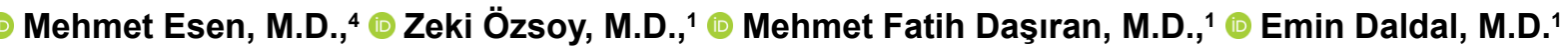

\author{
${ }^{1}$ Department of General Surgery, Gaziosmanpaşa University Faculty of Medicine, Tokat-Turkey \\ 2Department of Thoracic Surgery, Gaziosmanpaşa University Faculty of Medicine, Tokat-Turkey \\ ${ }^{3}$ Department of Internal Medicine, Division of Gastroenterology, Gaziosmanpaşa University Faculty of Medicine, Tokat-Turkey \\ ${ }^{4}$ Department of Emergency Medicine, Gaziosmanpaşa University Faculty of Medicine, Tokat-Turkey
}

\begin{abstract}
BACKGROUND: The management of food impaction and foreign body ingestion in the upper gastrointestinal tract requires careful evaluation and timely intervention. This study was a retrospective evaluation of the management of adult patients with such a history.
\end{abstract}

METHODS: This study included adult patients admitted to a tertiary medical center with foreign body ingestion or food impaction between January 2012 and January 2018. The demographic and clinical data were recorded pro forma for statistical analysis.

RESULTS: Of the 122 patients included in this study, $53.2 \%$ were male, and the mean age was $46.68 \pm$ I 8.64 years. In 84 of the patients (68.8\%), the ingested object was food. Thirty patients were managed solely through laryngoscopy, while $6 \mathrm{I}$ patients (50\%) underwent a flexible endoscopy. The patients with a foreign body ingestion were older than those with a food impaction (mean age: $51.3 \pm 17.4$ vs. $36.5 \pm I 7.4$ years; $p<0.00 I)$ and a plain radiograph showed the ingested material more often in those patients $(36.8 \%$ vs $10.7 \% ; p<0.00 I)$. Two patients underwent surgery due to perforations caused by the impacted material. No mortality was observed.

CONCLUSION: The management of a foreign body ingestion or food impaction in an emergency setting requires a stepwise, algorithmic approach.

Keywords: Endoscopy; food impaction; foreign body ingestion; upper gastrointestinal tract.

\section{INTRODUCTION}

Although foreign body ingestions and food bolus impactions in the esophagus are important emergency conditions, the real incidence is unknown. One study from the USA revealed an incidence of 13 out of 100,000 individuals. ${ }^{[1]} A$ food bolus or foreign object may travel through the entire gastrointestinal (GI) tract without any complications, and most of them will be successfully eliminated from the body if they pass through the esophagus. ${ }^{[2]}$ However, when the bolus or foreign object occasionally lodges in the esophagus or rarely in other parts of the Gl tract, it requires an intervention. While 10-20\% of the patients require endoscopic interventions, $1-2.7 \%$ of them undergo surgery. ${ }^{[3,4]}$

Foreign body ingestions are usually encountered with children, while food impactions in the esophagus are most often seen in adults. ${ }^{[5]}$ Food impactions are mainly associated with underlying esophageal pathologies, such as diverticula, webs, and malignancies. However, foreign body ingestions in adults are most often seen in psychiatric patients, patients with developmental delays, those with alcohol intoxication, and intentionally in detained persons for secondary gains. ${ }^{[6]}$ Many studies have investigated both ingestion and impaction

Cite this article as: Okan İ, Akbaş A, Küpeli M, Yeniova AÖ, Esen M, Özsoy Z, et al. Management of foreign body ingestion and food impaction in adults: A cross-sectional study. Ulus Travma Acil Cerrahi Derg 2019;25:159-166.

Address for correspondence: İsmail Okan, M.D.

Gaziosmanpaşa Üniversitesi Tıp Fakültesi, Genel Cerrahi Anabilim Dalı, Tokat, Turkey.

Tel: +90356 - 2149444 E-mail: hismail.okan35@gmail.com

Ulus Travma Acil Cerrahi Derg 2019;25(2):159-166 DOI: 10.5505/tjtes.2018.67240 Submitted: 25.06.2018 Accepted: 18.09.2018 Online: 14.03.2019

Copyright 2019 Turkish Association of Trauma and Emergency Surgery 
together, although the etiology, epidemiological distribution, and management can differ. ${ }^{[7]}$ Serious complications, such as perforations and subsequent death, can occur in both cases. The complications and severity are related to the ingested object, location, and duration of time that passes until treatment. ${ }^{[8]}$ Rarely, the intervention itself could result in complications. Moreover, fatal complications can occur in esophageal perforation cases if the treatment is delayed or the condition is unrecognized. Therefore, diagnosing and instituting the appropriate treatment promptly in both food impaction and foreign object ingestion cases are crucial. The management of these patients usually starts in the emergency department, and it is based on a careful evaluation of the patient through a history and physical examination. A radiological evaluation and referral to the relevant clinic for either laryngoscopy or upper Gl endoscopy are usually left to the personal judgment of the on-call physician in the emergency department. This reflects the common practice of the hospital based on the availability of the resources.

In this study, we aimed to evaluate the management of patients admitted to the emergency department with histories of foreign body ingestions and food impactions in the esophagus.

\section{MATERIALS AND METHODS}

The study was approved by the ethical committee of Gaziosmanpasa University Medical Faculty (registration number: 83116987-086). It was designed as a retrospective consecutive case series reflecting the experience of a single academic center (Gaziosmanpasa University Medical Faculty Hospital in Tokat, Turkey). The study group comprised patients admitted to the emergency department with a history of foreign body ingestions and food impactions between January 2012 and January 2018. The data was retrieved from the hospital's electronic records using the tenth revision of the International Statistical Classification of Diseases and Related Health Problems (ICD-I0) codes. Additionally, the data was cross verified with the electronic records of the endoscopy unit for foreign body ingestions and food impactions. Patients with airway obstructions due to a foreign body ingestion, food impaction, or bezoars of any origin were excluded. We also excluded patients aged $<16$ years of age. Children older than 16 years of age were managed in our endoscopy unit.

The patients admitted to the emergency department with foreign body ingestions and food impactions were initially evaluated by the on-call physician. After understanding the history and performing a physical examination, a radiological evaluation [direct radiography and thoracoabdominal computed tomography (CT)] was performed if needed, and the initial treatment was instituted in the emergency department. The decision to refer the patient another hospital unit was with the on-call physician, and it was based on their clinical evaluation of the patient.
The laryngoscopic interventions were conducted by ear, nose and throat (ENT) physicians without sedation in an outpatient setting, whereas the rigid endoscopies were conducted by thoracic surgeons under general anesthesia. The endoscopic interventions were performed in the endoscopy unit using both Pentax and Olympus flexible endoscopes. All the patients with foreign body ingestions and food impactions underwent emergent endoscopic interventions. Our endoscopy unit is located in the tertiary hospital of $X$ University, and it is the only referral center within a $100 \mathrm{~km}$ radius of the city. In this unit, on an average, 2500 upper $\mathrm{Gl}$ endoscopies are performed annually. It is an endoscopic facility available in the vicinity where on-call endoscopists perform emergency endoscopic procedures throughout the day and night. Each endoscopist (surgeons and gastroenterologists) performs an average of 400 upper Gl endoscopies every year. The patients were routinely prepared for the endoscopies, and pulse oximetry and blood pressure were monitored during the procedures. A standard sedation was used to achieve moderate sedation with intravenous midazolam and pethidine.

The patients underwent surgery when indicated, and the details of the surgical procedures are discussed in the Results section.

The data regarding the demographic features, clinical features (history, physical examination, and radiological data), endoscopic interventions, ingested materials, and operation details were retrieved and documented from the electronic files. Patients with foreign body ingestions and food impact were compared according to age, gender, physical findings, admission time, and detection of the object in radiography; an endoscopic management was performed. Thereafter, the patients were followed regarding whether they underwent a control endoscopy. Based on the electronic hospital records, the patients were also followed up for 3 months to determine repeated hospital admissions.

The statistical analysis was performed using the IBM Statistical Package for Social Sciences (SPSS ${ }^{\mathrm{TM}}$ ) statistics software, version 20.0, for descriptive analysis, and the groups were compared using a chi-square analysis. A p value of $<0.05$ was considered significant.

\section{RESULTS}

\section{Demographic Features And Clinical Findings}

A total of 122 patients (65 [52.8\%] males), with a mean age of $46.7 \pm 18.6$ years, were included in this study. According to the inclusion criteria, 109 patients (89.3\%) admitted to the emergency department with complaints of foreign object ingestions and food impactions and thirteen patients (10.6\%) were identified from the endoscopy and laryngoscopy records. These patients were either referred from other hospital emergency departments in the city, or they presented to the department. The main complaints upon admission were 
dysphagia $(n=75,61.5 \%)$, abdominal pain $(8.9 \%)$ sore throat (3.3\%), and dyspnea $(0.8 \%)$, and 31 patients $(25.4 \%)$ had no complaints. Twenty-one patients (17.2\%) presented to the hospital after 24 hours, while 70 patients (57.4\%) presented within 24 hours of the incidence. The history of 31 patients (25.4\%) lacked information about the timing of the incidence. The physical examinations in a majority of these patients $(n=111,90.9 \%)$ revealed normal findings. Radiographic evaluations of the neck, chest, or abdomen were performed in 76 patients $(62.3 \%)$, and in 23 patients (30.2\%), the swallowed material was visible on the radiographs. Additionally, 29 patients $(23.7 \%)$ underwent a CT scan of the thorax and abdomen, and in 22 patients (75.8\%), the scan revealed the object. The demographic features and clinical findings of the patients are summarized in Table I.

Table I. Demographic and clinical features of the patients with foreign body ingestions and food impactions

\begin{tabular}{|c|c|c|}
\hline & $\mathbf{n}$ & $\%$ \\
\hline Age, years (Mean $\pm S D)$ & \multicolumn{2}{|c|}{$46.7 \pm 18.6$} \\
\hline Gender & \multicolumn{2}{|c|}{ M/F: I.I4 } \\
\hline Male & 65 & 53.2 \\
\hline Female & 57 & 46.7 \\
\hline \multicolumn{3}{|l|}{ Symptoms } \\
\hline Dysphagia & 76 & 62.3 \\
\hline Abdominal pain & 10 & 8.2 \\
\hline Sore throat & 4 & 3.3 \\
\hline Dyspnea & I & 0.8 \\
\hline No complaints & 31 & 25.4 \\
\hline \multicolumn{3}{|l|}{ Admission time to hospital } \\
\hline Within 24 hours & 70 & 57.4 \\
\hline After 24 hours & 21 & 17.2 \\
\hline No information & 31 & 25.4 \\
\hline \multicolumn{3}{|l|}{ Physical examination } \\
\hline Normal & III & 90.9 \\
\hline Abnormal $(\ldots)$ & II & 9.0 \\
\hline \multicolumn{3}{|l|}{ Radiographic evaluation } \\
\hline X-ray of neck, chest, and abdomen & 76 & 62.3 \\
\hline Visible in $x$-ray & 23 & 30.2 \\
\hline $\mathrm{CT}$ of thorax and abdomen & 29 & 23.7 \\
\hline Visible in CT & 22 & 75.8 \\
\hline \multicolumn{3}{|l|}{ Endoscopy timing } \\
\hline Within 24 hours & 43 & 70.5 \\
\hline After 24 hours & 18 & 29.5 \\
\hline \multicolumn{3}{|l|}{ Ingested object } \\
\hline Food & 84 & 68.8 \\
\hline Foreign object & 38 & 31.1 \\
\hline
\end{tabular}

$\mathrm{CT}$ : Computed tomography; SD: Standard deviation.

\section{Management of the Patients}

Forty patients (35.8\%) underwent laryngoscopies by ENT specialists. Thirty patients (out of the 40 patients, 75\%) were managed solely by laryngoscopy. However, 10 patients required either flexible or rigid endoscopies. Sixty-one patients $(50 \%)$ underwent flexible endoscopies, whereas II patients underwent rigid endoscopies. The object was removed from 27 patients, pushed into the stomach in 7 patients, and pushed into the stomach after a piece was removed in 5 patients $(n=39,64 \%)$. In the remaining cases $(n=22)$, an object was either detected in the stomach and left in place or not detected at all in the endoscopy. The management of the patients is summarized in Figure I.

Forty-three patients (70.5\%) underwent endoscopies within 24 hours, whereas 18 patients $(29.5 \%)$ underwent endoscopies after 24 hours. The ingested object was food in 84 patients $(68.8 \%)$, and it was a foreign material in 38 patients (31.1\%). In 48 patients (39.2\%), the ingested object was not identified by any of the methods.

\section{Foreign Body Ingestion vs. Food Impaction}

The patients with foreign body ingestions were significantly younger than those with food bolus impactions (mean age: $36.5 \pm 17.4$ years vs. $51.3 \pm 17.4$ years; $p<0.001$ ). The plain radiographs were useful in significantly detecting the ingested materials in a greater number of patients with foreign body ingestions than those with food impactions ( $36.8 \%$ vs. $10.7 \%$; $\mathrm{p}<0.00 \mathrm{I}$ ). More patients with food impactions underwent upper $\mathrm{Gl}$ endoscopy than the ones with foreign body ingestions (61.9\% vs. $23.7 \%$; $\mathrm{p}<0.00 \mathrm{I})$. The gender, physical examination findings, the admission type (elective or emergency), or admission time did not differ between the patients with foreign body ingestions and food impactions.

\section{Recurrences and Requirement for Surgery}

Five of the patients had recurrences (4\%); however, these patients had associated diseases, such as cancer, achalasia, and mental retardation.

Two patients underwent surgery for perforations caused by the impacted material. One patient was admitted to the emergency department with complaints of a chicken bone impaction. The ENT department referral showed no object in the laryngoscopy; however, the CT scan showed the object and free air in the mediastinum, suggesting a perforation. First rigid and consequently flexible endoscopy revealed an impacted chicken bone, which was retrieved piecemeal using flexible endoscopy. A control endoscopy revealed the perforation site. The patient underwent an esophageal repair with a left cervical incision, and he was discharged after 10 days without any complaints. The other patient presented to the emergency department of a hospital with retrosternal pain, dyspnea, and shock. The personal history revealed that the 


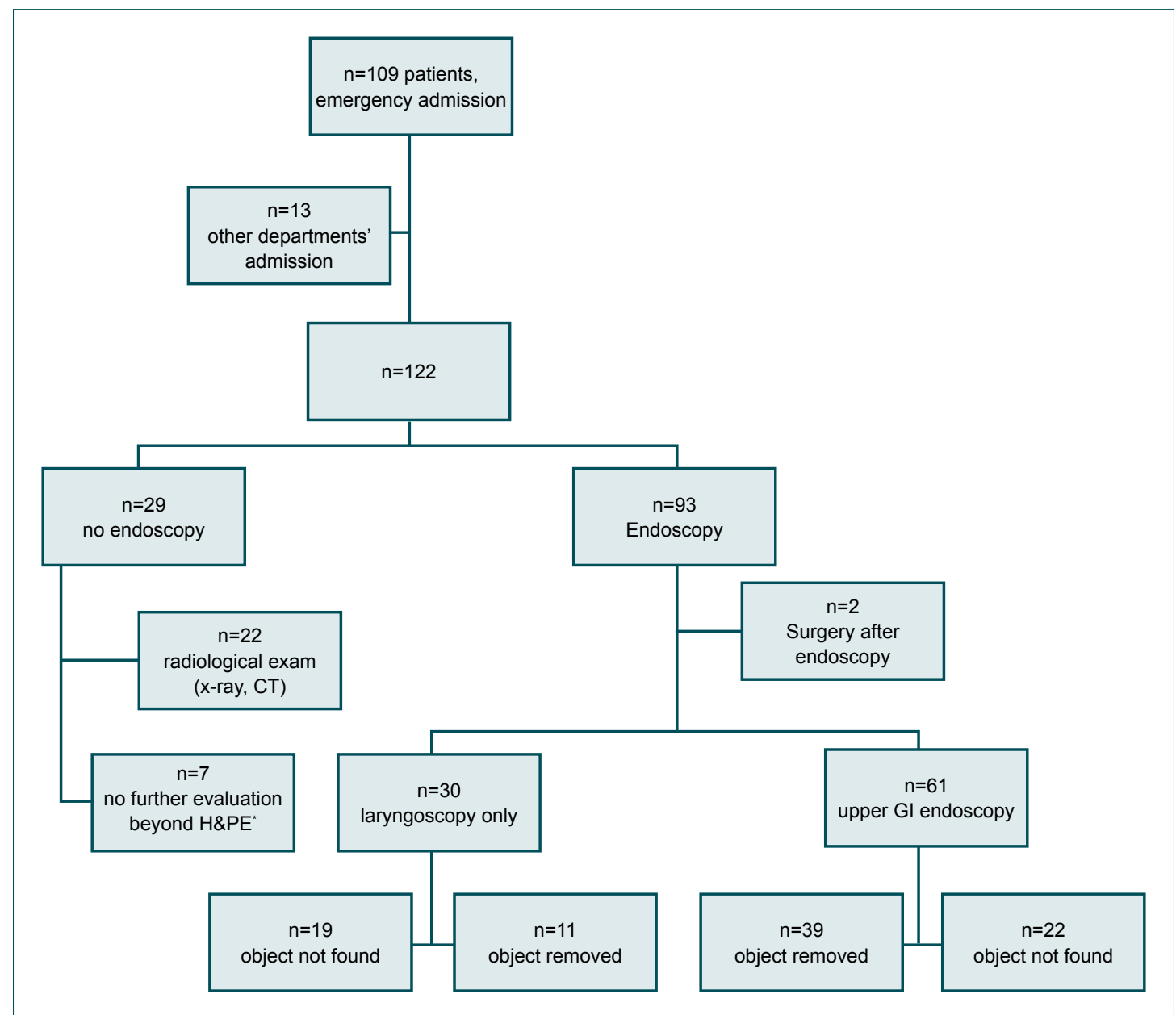

Figure 1. Summary of the management of patients with foreign body ingestions and food impactions.

patient had a history of an impacted meatball. The endoscopy revealed a perforation site in the middle of the esophagus. He was managed conservatively; however, 15 days later, after the patient's condition had deteriorated, he was referred to our hospital. A CT scan revealed an air-fluid density in the mediastinum and pleural and pericardial effusion. The patient immediately underwent right thoracotomy, the empyema was drained, and a stent was placed into the esophagus. The patient was discharged after 25 days with a prolonged, uneventful intensive care unit stay ( 10 days).

\section{DISCUSSION}

This retrospective study identified 122 adult patients admitted to the hospital with foreign object ingestions or food impactions in the esophagus between January 2012 and January 2018. The male to female ratio of these patients was nearly I. The management of the most patients was initiated in the emergency department. However, some of the patients presented to different clinics, such as surgery, gastroenterology, and ENT, with delayed admissions, or they were directly referred to the endoscopy unit. After obtaining the initial history and performing a physical examination, based on the clinical assessment of the on call physician in the emergency depart- ment, the patients were referred to either the ENT department or endoscopy unit. Although there are no standard criteria, a suspicion of ingested or impacted material in the upper esophagus may lead a physician to send the patient to the ENT department for a laryngoscopic evaluation. In our study, 30 patients underwent an ENT and laryngoscopic evaluation initially based on their complaints. Indeed, a recent study with fish bone impaction in the esophagus showed that a majority of the foreign bodies were detected in the oral cavity or laryngopharynx (69\%). ${ }^{[9]}$ Therefore, it was justified for patients suspected of fish-bone impaction to undergo a physical and laryngoscopic examination first followed by a subsequent detection and removal. Although some studies have also used rigid endoscopy in upper esophageal impactions, the associated disadvantages limit the widespread use of rigid endoscopy. ${ }^{[10]}$ The standard practice of the American Society for Gastrointestinal Endoscopy committee suggests an otorhinolaryngology consultation for foreign bodies at or above the level of the cricopharyngeus. ${ }^{\left[{ }^{\prime \prime}\right]}$ If the removal of the object is not achieved through laryngoscopy, flexible endoscopy is performed.

Foreign object ingestion occurs mainly in children, whereas food impactions in the esophagus are more commonly seen 


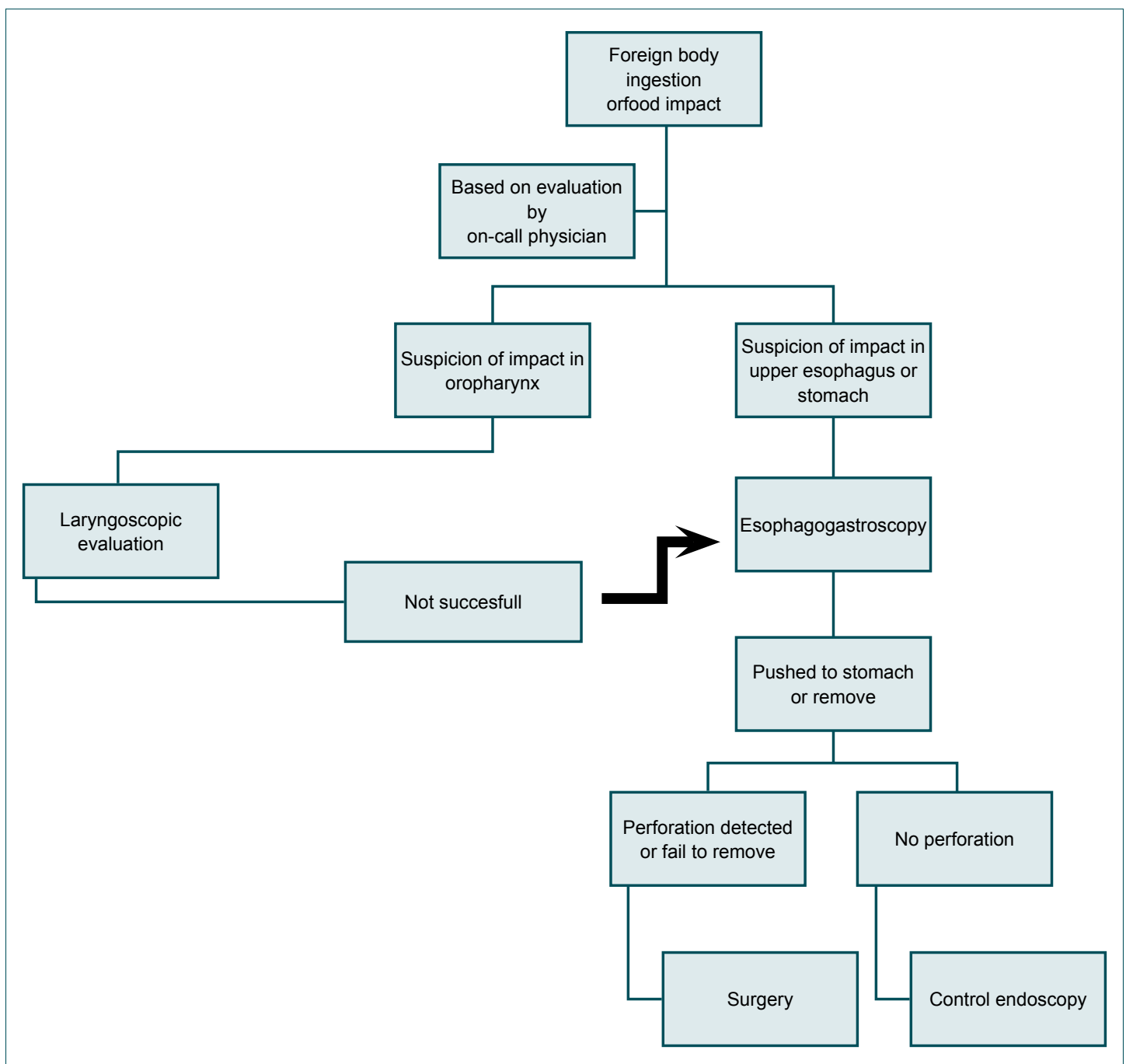

Figure 2. Management algorithm used for patients with ingested foreign objects or food impact.

in adults. However, foreign body ingestions occur more frequently in the elderly, psychiatric patients, and inmates. ${ }^{[2]}$ Here, we have also shown that there is a significant agerelated difference between foreign body ingestion and food impaction patients. Although the main symptom was dysphagia in our patients, nearly one fourth of the patients had no symptoms. This could be because when the object (food or foreign body) passed through the esophagus, most of the patients became asymptomatic, although many had sensations of a foreign body and retching in the throat, which persisted for quite for some time. A recent study showed that 15\% of the patients were asymptomatic, and majority of these patients $(50 \%)$ had their foreign bodies already located in the stomach and duodenum. ${ }^{[12]}$ The more pronounced presenting symptoms and signs, such as a fever, tachycardia, respiratory distress and shock, should alert the physician of the possibility of a perforation. ${ }^{[1,13]}$ If perforation has occurred, the clinical presentation changes according to the site of the perforation, the time that has passed since the perforation, and the characteristics of the perforation (whether it is contained or not). Upper esophageal perforations present as emphysema and stiffness in the neck, while thoracic perforations cause retrosternal pain and shock. Peritoneal irritation findings become more pronounced in abdominal perforations. Only one patient in our series presented with shock, and the patient was diagnosed with delayed esophageal perforation. That patient underwent subsequent surgery.

Although the first diagnostic radiological modality recommended for assessing the presence, size, and location of a foreign material is neck, chest, or abdominal radiography, not all foreign objects are visible. ${ }^{[2,14]}$ In our study, a radiograph showed a foreign object in only one-third of the patients, and the false negative rate for food impactions was higher than that of foreign body ingestions ( $89.3 \%$ vs. $63.2 \%$; $p<0.00 \mathrm{I})$. In some studies, the false negative rate of a plain radiograph was $47 \%$. This rate increased to nearly $87 \%$ in the food impaction patients because fish and chicken bones and meat pieces might not be identified via radiography. ${ }^{[2]}$ The clinical guidelines outlined by The European Society of Gastrointestinal Endoscopy (ESGE) for the removal of foreign bodies in the upper GI tract in adults do not recommend a radiological evaluation in case 
of a non-bony food bolus ingestion without complications, but they strongly recommended it in radiopaque object ingestions. The ESGE also recommends the selective use of a CT scan. ${ }^{[2]}$ In our series, only $23 \%$ of the patients underwent CT scans, and the yield for detecting the foreign object was high (76\%), in accordance with other studies. ${ }^{[14]}$ Therefore, CT scans are recommended for those patients with suspected perforations or other complications that may require surgery. [2] However, a CT scan was suggested as the first diagnostic radiological modality in fish bone impacted patients since the overall detection rate in a plain radiograph compared to CT for fish bones was $45.5 \%{ }^{\left[{ }^{9]}\right.}$

A majority of ingested objects pass through the $\mathrm{Gl}$ tract without causing any problems provided they traverse the esophagus. However, the size, shape, and nature of the foreign object determine the fate of the object in the Gl tract as it passes through the obstacles, angulations, and narrow path. Many of our patients did not undergo an endoscopy or endoscopic intervention (removal or pushing of the object). Patients with certain indications, such as sharp or large foreign objects, were followed via serial radiography or clinical observation. None of the patients presented to our emergency facility with complications such as an ileus or perforation. Conservative management of these patients within an outpatient setting has been suggested according to the ESGE guidelines, ${ }^{[2]}$ particularly for asymptomatic patients with negative radiographic findings. However, patients should be aware of the signs and symptoms of complications, and they must monitor their defecation daily. It is important to note that in some series for a fraction of patients (24\%) who applied to the emergency departments with foreign body ingestion or food impaction, the object could not be identified using endoscopy. ${ }^{[15]}$ If the object is radiolucent, it is almost invisible in radiographs. The lump sensation, odynophagia, or dysphagia could persist for a short time due to the irritation of mucosa.

Endoscopy is used for both diagnosis and treatment. According to the ESGE guidelines, patients with complete esophageal obstruction findings, disc battery, and sharp object ingestions should undergo urgent endoscopies within 6 hours. In patients without complete obstructions, the endoscopy should be performed within 24 hours. We divided our patients into two groups, one requiring emergency endoscopies and the latter undergoing delayed endoscopies. Although we could not specify the exact timing of the endoscopy, most of the patients underwent endoscopies within 24 hours in our unit. Since our endoscopy facility is always available with an oncall endoscopist, the endoscopy requirements were fulfilled in a timely manner. The flexible endoscopies were successful in all patients, and no surgeries were indicated due to failure to remove the object or perforation. This high success rate could be partially attributed to the timely procedures for the indicated patients. Rigid endoscopy is preferably used for the removal of foreign body from the esophagus in some eastern clinical practices with high success rates and low complica- tions. ${ }^{[15,16]}$ The authors have advocated that rigid endoscopy is more appropriate for proximal esophagus and more advantageous to remove the bigger chunks of food or foreign body due to the wider lumen for manipulation. However, some studies have claimed that the procedural duration is longer in rigid endoscopy compared to flexible and that the latter provides better examination of the esophageal mucosa. ${ }^{[17]}$ The complication rates in eastern practices did not differ between rigid and flexible endoscopies, which is possibly attributed to the experience of performing physicians or the variations in the foreign body. ${ }^{[15]}$ We preferred not to use rigid endoscopies (only in I I patients) because of the general anesthesia requirements and patient discomfort compared to flexible endoscopy. Moreover, it has been shown previously that rigid endoscopy is associated with increased complication rates, less patient comfort, increased dysphagia, and general anesthesia requirements. ${ }^{[10]}$ Although authors of the abovementioned study suggested an algorithm including the use of rigid endoscopy, we prefer to use of laryngoscopy in patients where the impaction was suspected at or above the level of cricopharyngeus (Fig. 2). The underlying organic and functional diseases are often associated with food or foreign body impactions in the esophagus. The most common causes are eosinophilic esophagitis, strictures, surgery, and esophageal motility disorders. ${ }^{[18]}$ In our series, only five patients $(4 \%)$ had recurrences. All but one patient had an associated disease or condition, such as an esophageal web, laryngeal cancer surgery, achalasia, and mental retardation. The reported recurrence rate reached up to $30 \%$ in one study where the presence of a diaphragmatic hernia, complexity of the endoscopic disimpaction technique, lack of follow-up, and visible severe esophageal disorders (suggested by an increased number of biopsies) has been shown to increase the risk of recurrence. ${ }^{[19]}$ Therefore, to prevent recurrences, the underlying disease should be treated either during the index endoscopy procedure or after the procedure, and the endoscopy should be repeated. ${ }^{[2]}$

Many studies have shown that foreign body ingestions mainly occurred in children. In our study, children were excluded, and the patients with foreign body ingestions were significantly younger than those with food bolus impactions (36.5 years vs. 5 I. 3 years). This could possibly be attributed to the associated esophageal functional disorders with increased age or the food habit of our region. Although the plain radiographs were significantly useful in detecting the ingested materials in more number of patients with foreign body ingestions than those with food impactions ( $36.8 \%$ vs. $10.7 \%$ ), more patients with food impactions underwent upper Gl endoscopy compared to foreign body ingestions (61.9\% vs. $23.7 \%$ ). Since the plain radiograph usually did not detect the radiolucent objects, such as meatball or fish and chicken bones, symptoms or a strong suspicion of impaction in the esophagus might have led more patients to endoscopy. The gender, physical examination findings, admission type (elective or emergency), or admission time did not differ between the patients with foreign body ingestions and food impactions. 
Only a minority of the patients required surgery (1.6\%). One patient underwent surgery due to a perforation detected immediately after the removal of the impacted food, while the latter underwent a surgery 2 weeks after the index food impaction. The latter case was complicated with empyema, and the discharge was prolonged. However, there was no mortality, and both patients recovered uneventfully. Surgery becomes necessary either due to the inability to remove the impacted object or perforation created by the object. In our series, there were two cases of surgery, both due to esophageal perforation caused by the object. Esophageal perforation is a serious clinical condition requiring prompt diagnosis and treatment. The type and success of the treatment depend on the time that has passed between the incidence and the operation, the clinical signs of the patient upon admission, the experience of the hospital, and inflammation severity. One systematic review has reported that the mortality due to a foreign object perforation was around $2 \% .{ }^{[20]}$ Nonoperative management can be used successfully in selected cases. ${ }^{[2]}$ In cervical perforation cases, a left cervical incision is performed, while thoracotomy and laparotomy incisions are used in thoracic and abdominal esophageal perforations, respectively. Early perforations can be managed with a primary repair ( 24 hours); however, delayed perforations require the consideration of other surgical options.

The limitations of the present work are in the retrospective nature of the study, and they all are shared with similar studies. Data collection directly from clinical practice may be another point for criticism. However, this might be acknowledged as an advantage because it reflects the actual practice.

In conclusion, our study denotes ordinary clinical practice in the management of patients admitted to the hospital with foreign body ingestion and food impaction histories. Based on the symptoms, patients evaluated by an on-call physician can be referred to either laryngoscopy (a sore throat or oropharynx impaction) or flexible endoscopy (dysphagia, chest pain or an esophageal obstruction). The foreign objects can be successfully removed or pushed into the stomach via endoscopy. Overall, a prompt diagnosis and treatment plan for esophageal perforations increase the success of the surgical intervention.

\section{Acknowledgments}

The authors wish to thank Yalcin Onder for his technical assistance in data analysis.

Conflict of interest: None declared.

\section{REFERENCES}

1. Longstreth GF, Longstreth KJ, Yao JF. Esophageal food impaction: epidemiology and therapy. A retrospective, observational study. Gastrointest Endosc 2001;53:193-8. [CrossRef]

2. Birk M, Bauerfeind P, Deprez PH, Häfner M, Hartmann D, Hassan
C, et al. Removal of foreign bodies in the upper gastrointestinal tract in adults: European Society of Gastrointestinal Endoscopy (ESGE) Clinical Guideline. Endoscopy 2016;48:489-96. [CrossRef]

3. Eisen GM, Baron TH, Dominitz JA, Faigel DO, Goldstein JL, Johanson JF, et al; American Society for Gastrointestinal Endoscopy. Guideline for the management of ingested foreign bodies. Gastrointest Endosc 2002;55:802-6. [CrossRef]

4. Lee HJ, Kim HS, Jeon J, Park SH, Lim SU, Jun CH, et al. Endoscopic foreign body removal in the upper gastrointestinal tract: risk factors predicting conversion to surgery. Surg Endosc 2016;30:106-13. [CrossRef]

5. Arana A, Hauser B, Hachimi-Idrissi S, Vandenplas Y. Management of ingested foreign bodies in childhood and review of the literature. Eur J Pediatr 2001;160:468-72. [CrossRef]

6. Sheth P, Finkelstein E, Campbell D, Danton GH. Imaging of foreign bodies in prisoners. Semin Ultrasound CT MR 2015;36:28-38. [CrossRef]

7. Webb WA. Management of foreign bodies of the upper gastrointestinal tract: update. Gastrointest Endosc 1995;41:39-51. [CrossRef]

8. Geng C, Li X, Luo R, Cai L, Lei X, Wang C. Endoscopic management of foreign bodies in the upper gastrointestinal tract: a retrospective study of 1294 cases. Scand J Gastroenterol 2017;52:1286-91. [CrossRef]

9. Woo SH, Kim KH. Proposal for methods of diagnosis of fish bone foreign body in the Esophagus. Laryngoscope 2015;125:2472-5. [CrossRef]

10. Gmeiner D, von Rahden BH, Meco C, Hutter J, Oberascher G, Stein HJ. Flexible versus rigid endoscopy for treatment of foreign body impaction in the esophagus. Surg Endosc 2007;21:2026-9. [CrossRef]

11. ASGE Standards of Practice Committee, Ikenberry SO, Jue TL, Anderson MA, Appalaneni V, Banerjee S, et al. Management of ingested foreign bodies and food impactions. Gastrointest Endosc 2011;73:1085-91. [CrossRef]

12. Yao CC, Wu IT, Lu LS, Lin SC, Liang CM, Kuo YH, et al. Endoscopic Management of Foreign Bodies in the Upper Gastrointestinal Tract of Adults. Biomed Res Int 2015;2015:658602. [CrossRef]

13. Khan MA, Hameed A, Choudhry AJ. Management of foreign bodies in the esophagus. J Coll Physicians Surg Pak 2004;14:218-20.

14. Guelfguat M, Kaplinskiy V, Reddy SH, DiPoce J. Clinical guidelines for imaging and reporting ingested foreign bodies. AJR Am J Roentgenol 2014;203:37-53. [CrossRef]

15. Tseng CC, Hsiao TY, Hsu WC. Comparison of rigid and flexible endoscopy for removing esophageal foreign bodies in an emergency. J Formos Med Assoc 2016;115:639-44. [CrossRef]

16. Zhang X, Jiang Y, Fu T, Zhang X, Li N, Tu C. Esophageal foreign bodies in adults with different durations of time from ingestion to effective treatment. J Int Med Res 2017;45:1386-93. [CrossRef]

17. Popel J, El-Hakim H, El-Matary W. Esophageal foreign body extraction in children: flexible versus rigidendoscopy. Surg Endosc 2011;25:91922. [CrossRef]

18. Kirchner GI, Zuber-Jerger I, Endlicher E, Gelbmann C, Ott C, Ruemmele P, et al. Causes of bolus impaction in the esophagus. Surg Endosc 2011;25:3170-4. [CrossRef]

19. Prasad GA, Reddy JG, Boyd-Enders FT, Schmoll JA, Lewis JT, Wongkeesong LM. Predictors of recurrent esophageal food impaction: a casecontrol study. Clin Gastroenterol 2008;42:771-5. [CrossRef]

20. Biancari F, D’Andrea V, Paone R, Di Marco C, Savino G, Koivukangas $\mathrm{V}$, et al. Current treatment and outcome of esophageal perforations in adults: systematic review and meta-analysis of 75 studies. World J Surg 2013;37:1051-9. [CrossRef]

21. Vogel SB, Rout WR, Martin TD, Abbitt PL. Esophageal perforation in adults: aggressive, conservative treatment lowers morbidity and mortality. Ann Surg 2005;241:1016-21. [CrossRef] 
ORİJINAL ÇALIŞMA - ÖZET

\section{Yetişkinlerde üst gastrointestinal sistemde yabancı cisim yutma ve gıda takılmasına} yaklaşım: Kesitsel bir çalışma

\section{Dr. İsmail Okan, ${ }^{1}$ Dr. Ahmet Akbaş, ${ }^{1}$ Dr. Mustafa Küpeli, ${ }^{2}$ Dr. Abdullah Özgür Yeniova, ${ }^{3}$ Dr. Mehmet Esen, ${ }^{4}$ Dr. Zeki Özsoy, ${ }^{1}$ Dr. Mehmet Fatih Daşıran, ${ }^{1}$ Dr. Emin Daldal ${ }^{1}$}

${ }^{1}$ Gaziosmanpaşa Üniversitesi Tıp Fakültesi, Genel Cerrahi Anabilim Dalı, Tokat

${ }^{2}$ Gaziosmanpaşa Üniversitesi Tıp Fakültesi, Göğüs Cerrahisi Anabilim Dalı, Tokat

${ }^{3}$ Gaziosmanpaşa Üniversitesi Tıp Fakültesi, İç Hastalıkları Anabilim Dalı, Gastroenteroloji Bilim Dalı, Tokat

${ }^{4}$ Gaziosmanpaşa Üniversitesi Tıp Fakültesi, Acil Tıp Anabilim Dalı, Tokat

AMAÇ: Üst gastrointestinal sistemde gıda takılması ve yabancı cisim yutulması dikkatli bir değerlendirme ve zamanında müdahaleyi gerektirir. Bu çalışma üst gastrointestinal sistemde gıda takılması ve yabancı cisim yutma öyküsü ile gelen hastaların geriye dönük olarak değerlendirilmesini amaçlamaktadır.

GEREÇ VE YÖNTEM: Çalışma Ocak 2012 ve Ocak 2018 arasında bir üniversite hastanesine yabancı cisim yutma ve gıda takılması şikayeti ile başvuran yetişkin hastaları içermektedir. Yaş, cinsiyet, başvuru semptomları, başvuruya kadar geçen süre, yabancı cismin niteliği, ilişkili hastalıklar, endoskopik yöntem ve girişimin tipini içeren demografik ve klinik veriler önceden hazırlanan bir dosyaya kaydedildi; tanımlayııı istatistik yöntemleri ki-kare testi kullanılarak incelendi.

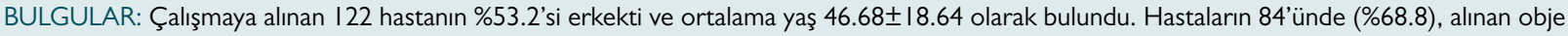
gıdaydı. Otuz hastada laringoskopi yeterli iken, 6I hastada fleksibl endoskopi uygulandı (\%50). Yutulan madde 23 hastada düz garfide saptandı (\%30.2). Yabancı cisim yutan hastalar gıda takılan hastalara göre daha yaşlı idi (yaş ortalaması; $51.3 \pm$ I7.4 ve $36.5 \pm 17.4$; $p<0.00$ I) ve düz grafide cismin saptanma oranı daha yüksek idi (\%36.8 ve \% I0.7; p<0.00I). İki hastaya yabancı cisime bağı perforasyon tanısılla cerrahi uygulandı. Mortalite saptanmadı.

TARTIŞMA: Acil şartlarda üst gastrointestinal sistemde takılan gıda ve yabancı cisim yutulması algoritmik bir yaklaşımla tedavi edilebilir.

Anahtar sözcükler: Endoskopi; gıda takılması; üst gastrointestinal sistem; yabancı cisim yutulması.

Ulus Travma Acil Cerrahi Derg 2019;25(2):159-166 doi: 10.5505/tjtes.2018.67240 